\title{
The Right for Regional Integration Organisations to Protect Democracy: Legitimacy at the Regional Level?
}

\author{
Katrin Nyman-Metcalf \\ Chair of Law and Technology, \\ Tallinn Law School, \\ Tallinn University of Technology \\ Akadeemia tee 3 \\ Tallinn 12618, Estonia \\ E-mail: Katrin.Nyman-Metcalf@ttu.ee \\ loannis Papageorgiou \\ Aristotle University of Thessaloniki, \\ Faculty of Law, Economics and Political Sciences, \\ School of Political Sciences, Faculty of Law, \\ Economics and Political Sciences Building, \\ Thessaloniki 54124, Greece \\ E-mail: ippg@otenet.gr
}

Abstract: Recently there have been several examples of different regional integration systems intervening to prevent unconstitutional events. The interventions can be based on explicit powers or be developed in response to events. This happens despite most regional integration systems having economic cooperation rather than explicit democratisation aims. Organs that issue laws or take constraining decisions must have a clear right to do this and a basis for exercising power-in other words, be legitimate. Where legitimacy comes from is debated, but as most countries today are democracies or purport to be, it somehow emanates from the people. National governments have a higher degree of legitimacy than regional integration organisations, possibly except the European Union. Regional integration organisations have to prove their legitimacy. The article examines if, to what extent, and on what basis regional integration systems have the right to exercise an independent role on the global stage. Legitimacy is a precondition for effective application of decisions of the organisation. Given the frequent lack of strong 
enforcement mechanisms, the question of legitimacy becomes even more important. With strong legitimacy, decisions taken by the regional integration organisation will be followed to a large extent even despite absence of effective enforcement mechanisms.

Keywords: African Union, ASEAN, democracy, enforcement, European Union, legitimacy, political community, regional institutions, regional integration, regional courts of justice, the Americas

\section{Introduction ${ }^{1}$}

Early in the morning of 13 July 2015, after 17 hours of negotiations at the summit of heads of state and governments of the Eurozone, the Eurozone agreed with Greece a third bailout package to keep the country within the euro. Participants to the summit hailed the result as a major step towards the normalisation of relations and further economic integration within the Eurozone. In contrast, the outcome was viewed by many citizens and parties, not only in Greece, as another proof of the unacceptable intromission of the European Union into national democracies and a further breach of national sovereignty. It is worth noting, in this regard, that during the summit, the hashtag \#thisisacoup became world trend among users of Twitter demonstrating the opposition of at least a part of the society to what was perceived as a violation of democratic principles. Indeed, during the brief campaign for the referendum called a week before by the Greek government on the bailout terms with the Eurozone, the main accusation against EU was the lack of respect for the sovereign decisions of the Greek people. This incapacity of citizens to understand - and of governments to explain - that, in matters pertaining to regional integration, decisions no longer fall exclusively within the ambit of national sovereignty is indicative of a fundamental problem for the European construction: the lack of legitimacy of European policy decisions.

This is not a problem exclusively limited to Greece; elections throughout the EU demonstrate that Eurosceptic parties draw a lot from the perceived illegitimate intromission of the regional bodies into national political systems. Neither is it a problem limited to Europe alone. Elsewhere in the world, regional integration

1 The matters discussed in this article are further developed in the recent book by the authors, see Nyman-Metcalf and Papageorgiou, 2015. An article (in Spanish) discussing partially the same issues will be published in the Revista de la Tribunal Permanente de Mercosur in 2016. 
organisations increase in numbers and expand in scope. States, conscious of the need to adapt to new situations arising from the rapid globalisation, tend to pool together their resources and forces, in an effort to safeguard economic prosperity. In addition, a common trend in recent years is that regional organisations gradually move from trade and economic cooperation to more political objectives. In doing so, they intervene more directly and more blatantly into what were considered 'national' matters and thus shake long-established perceptions of national democracies whereby national political communities (or national 'demos') provide legitimacy to such decisions.

Such 'intromission' also implies other unprecedented forms of implication of regional integration organisations. More and more regional organisation schemes include provisions to protect or uphold democratic institutions within their members and assert the right to involve themselves in constitutional matters, as defenders of constitutional legality. For instance, in recent years there have been a number of examples - including Cote d'Ivoire, Honduras, Mali or Paraguay - of regional integration systems intervening in some way to prevent unconstitutional taking of power or change in the form of government. This may be due to explicit tasks and powers set out in the constitutive documents of the regional integration system or it may be something the system develops ad hoc and in response to events. These interventions can be more or less successful, aiming to prevent unconstitutional developments or to revert to the situation before such events. Such action to preserve democracy happens despite the fact that most regional integration systems have economic cooperation aims rather than explicit democratisation aims. However, as previously explained, developments toward further regional integration in most parts of the world mean that the original aims and cooperation mechanisms tend to expand.

Such expansion, though, in particular any action taken by a regional integration organisation to safeguard constitutionality to be sustainable and have a potential to be effective, raises the issue of the status of the organisation conducting the intervention. The organ must have a legitimate basis for taking action to preserve a legitimate system!

Organs that issue laws or take decisions, especially when such decisions constrain actions of any party, must have a right to do this, with a proper basis for exercising power. Another way of expressing this is to say that the organ must be legitimate. Where the right — or legitimacy — comes from is a matter of debate, but as most countries today either are democracies or purport to be, the right and thus the legitimacy emanates from the people. There are still systems that find other sources for the right to govern, such as religion or inheritance, 
but even in such circumstances the right is often linked to a certain group of people, the citizens. Legitimacy does not need to be absolute, but may be partial or conditional.

National governments have a higher degree of legitimacy than regional integration organisations. Even the European Union, long established as the most further-reaching integration scheme cannot compete in this field, as the Greek crisis demonstrated. In general, regional integration organisations have to prove their legitimacy in a different way than that which applies to states. States have a historically established structure where the constitutional order is protected and respected, because of its link with a politically legitimate authority that enforce rules and orders. This exact same type of legitimacy cannot easily be transferred to the international arena (Focarelli, 2012, p. 125).

\section{The aim and structure of the article}

This article does not intend to delve into the significance of legitimacy in the European process. Rather, it examines legitimacy from a more comprehensivetheoretical as well as practical-perspective. Asserting regional legitimacy can be crucial for the success of regional integration organisations, all over the world, and for all regional organisation processes: the avowed objective of enhancing democracy and increasing the right to intervene in previously considered national ambits (from the economy and the role of the state to the protection of individual rights and constitutional legality) can only be achieved, among democratic societies in Member States, if it is perceived as legitimate. The objective of this paper, therefore, is to analyse to what extent and especially on what basis regional integration systems have the right to exercise an independent role on the global stage and acquire or create legitimacy as a precondition for the effective application of the decisions of the regional integration organisation. Given the lack of strong enforcement mechanisms that usually is the case with regional integration organisations, the question of legitimacy becomes even more important. With strong legitimacy, decisions taken by the regional integration organisation will be followed to a large extent even despite the absence of effective enforcement mechanisms. To this end, the article shall examine at a first stage how legitimacy is founded and how it is possible to set or strengthen legitimacy through creating regional political communities (a regional 'demos'). In addition, it examines possible regional differences in the degree and potential of regional legitimacy as well as institutions required to 
that purpose. In conclusion, it examines how legitimacy of regional integration can be enhanced and how this enhancement can be beneficial for international democracy in the long run.

In order to examine legitimacy outside of the context of states, trade agreements and organisations that purely unite states for trade purposes are not examined. Trade relations may be the starting point for deeper integration, but this depends on the setting. Global or inter-regional trade agreements (such as the topical Transatlantic Trade and Investment Partnership between the EU and the U.S), for example, rarely have any potential to develop into anything more than just that: trade agreements, however important. At the same time, such relations may develop into deeper regional integration in the economic sense even if the relationship remains on the economic and trade related level. If there is a point where such deeper economic integration cannot any more remain purely economic is an interesting question (Marquez-Ramos, Martinez-Zarzoso \& Suarez-Burguet, 2011, p. 482), but this would be the topic of a separate and different article, as we take as our starting point integration systems that subscribe to an idea of integration beyond the economic realm.

The structure of this article is that we outline the substance of legitimacy-what it means in general-before moving on to regional characteristics. Following this, the article reverts back to general aspects of legitimacy that, although presented in a specific context, are applicable in different regional contexts. This includes expectations, institutions and the hierarchy among institutions. On the basis of these elements it is possible to make an evaluation and reach conclusions.

\section{The substance of legitimacy}

Legitimacy is a way of expressing the link between the ruler and those being ruled - the reason why someone has a right to issue rules with an expectation that these should be followed. It is more than legality, which just means adhering to rules, without questioning where the rules come from. Legitimacy includes accepting that rules are made by a certain organ (Focarelli, 2012, p. 245). The question of why someone can rule over someone else is a very old philosophical question. The answer to it has varied through history, but interestingly the basic content of the question remains similar. The right to rule is either given from some abstract, superior power (such as God) or it is created. If the direct link to religion does not play a significant part in modern legal philosophy, the question 
of where human rights come from and if a ruler can rule in any way or has to abide by some universal human rights is still topical and in many ways just another way to look at the same thing: is the legitimacy of the ruler and the way he/she rules something created or something that exists in any case?

A legitimate regime has been described by Mather (2006, pp. 12-13) as a regime with a normative element (rule bound and justifiable), demonstrable popular consent, enabling citizens to identify with it, that is authoritative, and meets popular expectations. In a globalised world with trans-border problems that individual states can only partially handle, as far as meeting expectations of efficient decisions is concerned, the legitimacy criteria could potentially fit international bodies, like regional integration systems, even better than states. Mather says that legitimacy, the link between rulers and the ruled, is a prerequisite for successful political government. She divides legitimacy into a shared conviction, an artificially created device, an accepted system and something invested in a particular person or government, which can be built on trust or allegiance (interpersonal or institutional). Legitimacy contains a normative element as expectations on the governing system and the laws must be met. (Mather, 2006, p. 10) Measuring legitimacy can be done in a concrete manner by studying the acceptance of decisions of an organisation, seeing how often they lead to the desired effect. The EU appears to have strong legitimacy as most of its decisions can be implemented. Such objective study, however, may not fully answer the question on legitimacy as we need to examine if this is legitimacy or just law-abidingness?

It is essential that the basic unit from which rules emanate should be legitimate. Such unit has to have powers that it can use itself or give away, through a permanent mechanism of delegation or through one-by-one decisions. In the current international legal system this basic unit is the state. Legitimacy of organs consisting of states can be derived from the legitimacy of the state. If the states retain the ultimate decision-making power in the international organisation there is in principle no need to search for additional or different legitimacy. ${ }^{2}$ The international organisation is just another way for the states to exercise their legitimacy. Another question is that of regional integration

2 It remains, nevertheless, that in some cases, for instance in the case of international humanitarian interventions, it is useful to invoke some form of supra-national legitimacy. See, for instance, the justification of the U.N. Security Council resolution 794/1992 allowing for the intervention in Somalia which stated the "urgent calls from Somalia for the international community to take measures to ensure the delivery of humanitarian assistance in Somalia", as well as similar references in U.N. S.C. resolution 688/1991 establishing a no-fly zone in Kurdistan. 
organisations (or other international organisations) taking decisions that are not under the direct control of or even under the authority of states. This can be in the form of majority decisions, decision taken by institutions where states are not represented directly or decisions of autonomous regional courts of justice. The competence to decide is still conferred as the organisations are created by states, but with the creation of the organisation, the direct link back to the member states for every decision was severed.

With the growing autonomy for regional integration organisations the basis for legitimacy becomes thus more complex than a mere collection of legitimacies of the member states (Nyman-Metcalf, 2013, pp. 93-97). In order to determine the role and potential influence of regional integration organisations, the status of such organisations vis-à-vis the member states is essential- more specifically if the organisation has any possibility of playing an independent role. The further an integration progresses, the more it can be seen that the organisation is not just a mouthpiece of its members but that the sum of parts can actually be more than each part separately. The best example to study is, unsurprisingly, the EU, being the furthest reaching integration system. Bieber (2009, pp. 397-398) mentions examples of things that no single state could do on its own, like imposing fines on companies outside of its borders or fixing customs tariffs for other states. No individual state, even a big one, would have legitimacy for such action visà-vis the subjects of another state. A regional integration system can create a legitimate setting for such actions of cross-border relevance.

Focarelli (2012, pp. 144-145) points out that authority may relate to persons or to norms and refers to the classical Weberian interpretation that authority exists when commands can be expected to be followed. Even if there may be many levels and many reasons why this happens, the current international system is still construed around states and the state authority as the ultimate reason why commands are obeyed - whether they are commands from private bodies or statecreated ones. (Focarelli, 2012, pp. 144-145) Focarelli does not deal specifically with regional integration systems and for such systems the additional question is whether the authority that the state possesses at some point may actually be transferred or simply move to another organ of which the state is a part. 


\section{The foundation of legitimacy: A regional demos}

Contrary to states, a regional integration organisation does not, in general, draw its legitimacy from people's emotions or feelings of patriotism and identity, of belonging to a certain group or of attachment to a certain territory. ${ }^{3}$ Such feelings will enhance the legitimacy of a state and for states that for various purposes have problems with national unity, the solution is found in enhancing the feelings of belonging of all groups. Most people accept the legitimacy of states. Those (minorities, for example) that may challenge the state most often do not challenge the state as such, but its borders or government.

There may be exceptional cases where it is the division into states in a certain region that is the anomaly, and historic or emotional ties instead link people across state borders. The emotional link can come after a while, which to some extent can be seen regarding the EU. ${ }^{4}$ Williams is concerned that the EU did not from the start have the ideological notion, including that of democracy that an organ of a certain type needs. In his view, the latter attempts to inscribe democracy as a value that the EU supports in provisions on citizenship or transparency for example are "vaguely desperate". He also sees ambivalence regarding the rule of law. (Williams, 2009, p. 568) However, one can question if the philosophy is a prerequisite for building up a regional integration system or it comes into the picture later. Williams' ideas are linked to the debate on whether there is a European demos, a people through which the demands for democracy can be raised.

Schütze (2009) discusses whether the people, the constituency, have to precede a polity or if it can be the result of it. It is not only for regional integration organisations that the question arises, as there are also many examples of multinational states where the people of the state is a political and constitutional creation rather than based on ethnic or historic circumstances. In such cases, as in the EU, notions of what Schütze calls dual citizenship (albeit in a different meaning than the regular one for this term-citizenship of more than one country) have been created: being citizen of several layers of a constitutional or

\footnotetext{
3 Von Bogdandy (2008, p. 252) discusses the cultural aspects of the EU, whether it strengthens or challenges cultural diversity.

4 Karl Deutsch enumerates a number of "essential requirements" for the establishment of political communities among states in the 1957 seminal paper 'Political community and the North Atlantic Area'. Among them is the gradual transfer of political loyalty from the smaller political units to a larger one when there is a "partial shift in political habits" created by gradual "connection between values, institutions and habits". See Deutsch, 2003, p. 127.
} 
other creation, like the EU citizenship (Schütze, 2009, p. 64). One legitimacy does not exclude another as long as they are not incompatible by content.

There is no clear answer to what it takes to create a political community, a demos. The nation state is after all a relatively new invention and far from all states rely on a unified population, based on criteria of ethnicity, race, religion or language. Indeed, it is often the arbitrarily created nation state borders as well as the legal and political system based on these borders that is the only thing that holds the demos together. There should thus not be any obstacles to creating a demos also for a regional integration system. However, in a ruling of the German Constitutional Court in June 2009 on the legality of the Lisbon Treaty the influential court underlines that the Treaty is based on the understanding that democracy, self-determination and citizenship derive from the sovereign state (BVerfG, 2009). A state must have a people and as long as there is not one united people in the regional integration organisation (in this case the EU), such an organisation cannot replace the state (Bieber, 2009, pp. 396-397). Many authors (among them Bieber, 2009, pp. 396-397) have criticised the ruling as not being consistent neither with theories of democracy and transnational governance, nor with the realities and intentions of the EU. Nevertheless, the ruling has been influential for how the legitimacy of EU post-Lisbon is seen.

\section{Regional differences}

One basic element for legitimising regional integration in the minds of people (leaders as well as populations) is that the region is seen as a real concept. There needs to be a shared interest in issues and other factors that bind states together. ${ }^{6}$ Different regions of the world show examples of significant differences in this respect. In Asia, there are vast inter-Asian differences so an Asian attitude to international relations is harder to determine than a European such attitude. Also, when Europe has seen integration and cooperation as a way to get more power on the world stage, in Asia strategic alliances with great powers have been

\footnotetext{
The Treaty on European Union and on the Treaty on the Functioning of the European Union, 13 December 2007, entry into force 1 December 2009.

6 The lack of this as a factor hindering closer cooperation in Asia in the ASEAN+3 framework is discussed by Takashi Terada, see especially Terada, 2006, p. 227. The Asian financial crisis of the late 1990s made countries aware of their interdependence and the common interests that they in fact had. This prompted regional leaders to ask why Asia alone among the three poles of the world economy should not have a regional bloc to speak for it.
} 
favoured. Multilateralism in Asia has often been seen as a way to preserve state sovereignty rather than transcend it (Acharya, 2006, pp. 317-318). In Africa there may be a common identity through a similar history (like in the postcolonial struggle) but with time, regional rather than pan-African groupings may be more likely to rely on such a common identity. A large part of the Americas share a common language and also some common history and there are some signs this may belatedly lead to integration although it has so far not had much of this effect. The need for at least a certain level of similarity in political systems for deeper integration can be seen in all different regions. ${ }^{7}$

Clearly the mindset of states (if such a thing can be imagined) plays a role for the success of integration, together with practical matters such as how well institutions function and similar. One example can be taken from ASEAN+3, an attempt to bring big powers like China, Japan and Korea closer to the rest of the region - the members of ASEAN. Mental barriers may hinder cooperation, but as is suggested by Tang (2006, p. 81), may also favour it, if the big powers are unable to overcome mutual suspicion, but may learn to cooperate through a multilateral framework in a way that would not be possible bilaterally. As Terada (2006) puts it, the habit of cooperating can be conductive to strengthening shared beliefs and promoting further cooperation and consensus. Not only will there be a useful exchange of information through cooperation, but the nations can learn solidarity and understanding of social and cultural differences, which will support increased cooperation. (Terada, 2006, p. 233)

The EU appears to have strong legitimacy as seen through the acceptance of its decisions, but even so the question arises if this is legitimacy or just lawabidingness? There are many debates on the exact limits of competence between the EU and its Member States, both on what is suitable de lege ferenda and what it in reality is de lege lata. However, there are few serious commentators that would question the legitimacy of the EU as such. The legitimacy has been built up through the powers given by member states to the organisations so like the powers of it, the legitimacy is derivative. This derivative nature of the EU is made clearer in the Lisbon Treaty. The EU shows examples of indirect increasing of legitimacy (if you accept the decisions on something of one organisation because they are usually good, you will accept the decision also

7 This prerequisite, for European integration in particular, has been crystallised in the writings of Chris Wheare (1951, p. 37) already in 1946 after the World War II when he spoke about the "similarity of political institutions" and, more recently, in 1986 by Mario Albertini (1999, p. 296) who insisted on "the representative system of government, with the possibility of dual representation through the dual citizenship of each voter". 
on other things by the same organisation - which is why even something as technical as competition law helps to increase the overall legitimacy of the EU).

\section{Expectations on legitimacy}

There are certain general expectations about what a state can and should do. If such expectations are not met it challenges legitimacy, as the reason for accepting that a state enforces also unpopular decisions is a kind of more or less conscious trade-off: in exchange for accepting the use of coercion and even force, there will be other benefits. States that are only partially recognised, such as Kosovo, show how the state cannot perform all the functions that would be expected from it, but as long as a majority of the population see this as a result of external factors, the state does not necessarily lose its legitimacy.

A regional integration system may similarly be subject to various expectations and different factors will determine if these can be met. If the expectations on a certain body such as a regional integration system are low or diffuse, it may well be able to meet these expectations, but only because they are set at a very low level. If the expectations are turned up (for example that the regional integration system can guarantee democracy, safeguard individual rights or provide prosperity) without the means being given to it to undertake any real measures to that effect, the legitimacy suffers. Legitimacy, being created by the very process it is created for, may look like an unsolvable chicken-and-egg question, ${ }^{8}$ but rather than taking this view, it should be seen as a series of factors, including expectations, that compose a web. For a state there are certain given factors that form the main part of this web, whereas for a regional integration system the components of the web are less clearly defined.

Bieber $(2009$, p. 400) finds that individual self-determination in any society will entail a multitude of different loyalties and cannot be expressed just as getting the nationality of a state. States can expand the scope of democratic choice as well as the possibilities for democratic control if they pool and delegate competences - and even sovereignty. Individuals can experience a

8 Mather (2006, pp. 173-174) discusses the same chicken-and-egg question regarding the European Parliament, which cannot be given too big powers as it lacks proper legitimacy and which does not attract the required attention in the form of participation in the vote, etc., to make it worthy of greater powers. She interprets this as a misguided attempt to just insert liberal representative democracy on the EU system without it necessarily fitting it. 
stronger protection of democracy and human rights through regional integration. Bieber (2009, p. 400) brings the European Convention and Court of Human Rights and rights deriving from EU law as examples. He states: "Establishing a constitutional setting which combines the exercise of power at national with supranational level may increase the inclusiveness of the exercise of power, the respect for minority rights and its efficiency, because it may be a more genuine reflection of the interest of the peoples" (Bieber, 2009, p. 400).

Williams (2009), on the other hand, stresses the failure of the EU to establish strong democratic structures as something that serves to diminish conceptions of liberty in the EU. Early on in the history of the then EEC, the European Court of Justice (ECJ) did not pay much attention to enforcing democracy. (Williams, 2009, p. 568) Williams puts these weaknesses down to an absence of a philosophy of law for the EU. For other systems of regional integration that are far behind the EU, as concerns the strength of the integration as well as the tasks and competences they have, it may be premature even to think of a philosophy. Or, it may be so that the philosophy that the regional integration structure supports should be there at an early stage rather than somewhat as an afterthought added to a structure created by compromise?

Different types of relationships between states can be more fruitfully exploited through a regional integration system than in bilateral relations. Lake (2009, pp. 40-42) elaborates on how certain (weaker) states accept to be subordinate to a strong state if this is done through a regional system and how the fact that many states in a region have a similar kind of relationship may increase the attractiveness of the system as such: The stronger state will deal with issues between the weaker ones as they all have a similar hierarchical relationship to the stronger one. A separate issue is how to ensure that all relevant players take part and some states do not try to be free riders of the benefits of a system without any of the burdens of accepting a certain subjugation - they want to know a powerful state will protect them but they do not accept that this powerful state is hierarchically above them. Lake (2009, pp. 40-42) takes the U.S. involvement in Europe and especially its support for the creation of a democratic West Germany as an example. In this context, the regional organisations created, such as NATO and the clause on mutual guarantees in the NATO treaty, should ensure that states do not have to accept the orders of one country- the U.S.- as such, but the positive effects of one dominant country over others (especially the occupied West Germany) can still be achieved and without free riders. (Lake, 2009, pp. 40-42) 


\section{Institutions of legitimacy}

It is possible that a particular state may have to struggle to establish its legitimacy, but the framework for this is well established (Nyman-Metcalf, 2013, pp. 8387). What such struggle will typically concern is how to include different ethnic groups in a state or whether a particular part of the territory should form part of the state. Sometimes such struggles are linked to claims from other states to territory (or even to people, as the Russian aggression against Georgia in 2008 and Ukraine in 2014 with the stated aim to protect Russian citizens showed). The struggle will not be to gain acceptance for the idea of a state - only for the idea of that particular state.

Regional integration organisations have a different starting position in that they first have to establish that the very organisation as such can have any legitimacy at all - that a body like a regional integration organisation can participate in the global system. The organisations have to construct its legitimacy in a different manner than a state. They start out without any inherent legitimacy, they cannot obtain legitimacy automatically from anywhere; instead, legitimacy will be created as a direct consequence of decisions, institutional structure as well as through the increased credibility and influence of the work of the organisation. Method and effect are part and parcel of the same processes. This means that the legal instruments setting up the regional integration organisation as well as the institutional structures supporting the functioning of it, will help to create the legitimacy that after a certain time will be able to fulfil a role to actually support these same institutions.

Regional integration structures are created through international law and the instruments and methods available in this legal system. What is created may however be something that is outside of regular international law and goes further, a sui generis structure. De Witte $(2009$, p. 269) points out how international law is very free concerning what forms of agreement are available for states. The case is different for many regional integration systems, especially the EU, where the freedom of form is much more limited. One element of the sui generis character of EU law is that Member States have bound themselves to act within the system, also when it comes to, for example, changes to the treaties (De Witte, 2009, p. 269). This legal construction is important for the strength of the regional integration system, to afford it a sense of permanence.

Mattli (1999) calls organs like the ECJ and the Commission in the EU 'commitment institutions'. These provide for monitoring and enforcement in a 
manner that is out of the hands of the member states directly. Such institutions are prerequisites for a successful regional integration system, in Mattli's view together with market pressures and a regional leader or hegemon. (Mattli, 1999, pp. 13-15; see also Webber, 2006, p. 302 and fn. 8)

Courts of Justice have a very important role in the institutional structure of a regional integration. Courts and a legalistic interpretation of tasks of the organisation give the regional integration its contours; they help to show the potential of an organisation. This strengthens the organisation as the functional success may lead to a legitimacy that reaches outside of the actual functions carried out (Nyman-Metcalf \& Papageorgiou, 2005). Courts can strengthen the rest of the institutional structure and determine the division of competence between the organisation and its member states. This constitutional role of the court will make the organisation different from international organisations with a more limited mandate, where there is no independent organ to determine division of competence but, instead, this is done by the members themselves. Another essential role of the regional court is to ensure abidance to the principle of rule of law in the regional integration system.

For enforcement of decisions in a rule of law state, there must be corresponding access to justice. If a regional integration system is created without such guarantees, it could rightly be seen as a weakening of the rule of law. This would be the case also if the system made access to justice more complicated, even if it did not make it impossible. For a positive impact of a regional integration system on rule of law and democracy, the effective enforcement combined with guarantees of legal accessibility (including appealing decisions to a judicial organ) are a necessary prerequisite.

\section{Hierarchy or anarchy in the global system}

In modern political debates, especially in the EU, regional integration systems are often criticised for being too far from the people and for leading to alienation of populations from decision-making. This is also a problem as regards legitimacy. The sovereignty of states and their possibility to decide over their own matters, however, is challenged by globalisation, which means that in many cases a state cannot decide over various issues independently even if it formally and according to international law has sovereign power. Schneiderman (2006, p. 390) expresses it so that economic globalisation has disrupted state functions and relocated its authority upwards, downwards 
or nowhere at all. For economic globalisation there is both regulation and deregulation, changes within and without national legal systems (Schneiderman, 2006, p. 390). This fits the economic relations that Schneiderman writes about, but when it comes to state structures and fundamental decisions, the state retains its powers, although even here that power may be circumscribed by networks of international relations. The kind of developments Schneiderman discusses may raise issues of legitimacy as the traditional features upon which the role of states are built (the social contract) do not present themselves, but there needs to be some new reason to support transnational legitimacy. (Schneiderman, 2006, pp. 390-392) ${ }^{9}$

Schneiderman's main message is the continued necessity of the state, the local level, within the globalised systems. It is not convincing in his arguments that a transnational system cannot have its own legitimacy if this is built up over time and rests on solid foundations, as he does not convincingly answer why a state that holds legitimacy could not transfer this to a different institutional structure. If the way this is done and the guarantees built into this structure are sufficient, there is no reason why legitimacy should disappear along the way. Today the only way to achieve transnational legitimacy is that states create this, as states are the building blocks of today's system (Collins, 2009, pp. 276277). It is important that transnational rules are followed and implemented, for which in the current international system states are necessary (Schneiderman, 2006, p. 394). Even in the EU, by far the furthest reaching regional integration system, the states are responsible for implementing and enforcing EU law. However, the system includes sufficient guarantees and mechanisms to ensure that such implementation takes place - in some ways making states the tools for the common policy. Schneiderman (2006, p. 404) finds states essential in structuration of transnational legality, in limiting some of the effects of the economic decisions because of social consideration.

Often in regional integration systems there is in fact a hierarchy between states that is set out in practice rather than by any legal documents. It is very rare that states will formally accept hierarchy of states where they are not all equal. In practice, if there are perceived benefits of such a system it is possible that state do accept it. Possible examples may be found in monetary issues (accepting the currency of another state, so-called dollarisation but not just restricted to the dollar, see Lake, 2009, pp. 46-47), trade relations where a state may allow another state to decide conditions also for its relations with third countries, but

9 One main point of Schneiderman's article is a criticism of Hard and Nedri's theories on the obsolescence of the state in the globalised system. 
most clearly the hierarchy and acceptance of decisions of another state can be seen in defence related cooperation (exchanging sovereignty for protection).

Lake (2009, p. 36) argues that the assumption that regional integration systems, like the international system in general are anarchic, as there is no higher legal power than the state, is not necessarily correct or at least not the full truth. Such a view is based on a formal-legal conception of authority and disregards from the possible informal hierarchy (Lake, 2009, p. 36). That it is clear that the global system is anarchic in that it lacks an authority above its members does not translate into all sub-systems consisting of states being equally anarchic. Authority is fundamentally a social contract also between states, where certain states have a duty to comply with orders of another state-which has the legitimate right to issue orders. In regional integration systems, lawful institutions must be created by the states that form part of the system as there is no other authority to do this. Certain states may accept the authority of others or, more usually, of one dominant state if they get something in return for such acceptance. The acceptance of a legitimate right of a state to decide over another may cover certain issues rather than being total. (Lake, 2009, pp. 38-39) In a regional integration system, it is more likely that states accept to be bound by decisions of others.

The argument of Lake illustrates that real power and hierarchies not based on formal legal instruments but rather on dominance in reality by one state may be conductive to certain behaviour of states, which they may express through a regional integration organisation. As for Europe, Lake takes the EU as an example of how a regional organisation can replace the dominance of one state, in Europe the dominance of the EU, and how through greater institutionalisation an alternative system and an emergent European identity can be created. Lake, however, feels that instead of institutions, a measure of international hierarchy and authority is needed to protect, constrain and discipline member states. (Lake, 2009 , p. 56) This is an interesting argument and although one can agree on the need to have constraints, in the international system the equality and sovereignty of states can be protected if such constraints are created and given to the system rather than held by one state that is powerful enough to dominate others. 


\section{Concluding analysis}

This article discusses the prerequisites for the regional integration organisms to achieve a position which allows them to exercise an independent role on the global stage and possess and exercise a legitimacy of their own. It is not an analysis of any specific regional integration system and specifically avoids concentrating too much on the EU, as this organisation is so much furtherreaching than any other regional system and thus often presents sui generis solutions that may be difficult to apply in a different context. What we show is how legitimacy in any regional context may be achieved.

The Centre for Studies on Federalism $(2009$, p. 3) in its study on international democracy points out that the response of governments to globalisation has been to pursue international cooperation, not because it is their inclination, but because they have no other choice. With such an interpretation, the expansion of international organisation as a phenomenon is due to governments looking for solutions that they cannot find on their own. However, international organisations may not always provide the solution as they have their own limitations. The Centre in its report states that the most visible and serious such limits are to be found in their decision-making procedures, normally based on unanimity and national veto and ensuing lack of effective (limited but real) supranational powers (The Centre for Studies on Federalism, 2009).

Contrary to states, legitimacy for other organisms such as regional integration systems is not 'innate' but rather an 'acquired' characteristic, a result of a long process of empowerment and consolidation. It requires not only a significant increase of their powers allowing for the taking of decisions that are seen to be autonomous from member states and that are seen by other actors and states citizens to be autonomous, but also that there is an at least tacit acceptance of states to accept such development. The acceptance of states in a democratic system includes an acceptance by citizens. The accusations that regional integration is an elite project that is negative for ordinary citizens are heard from Eurosceptic parties in many EU countries but also from similar political forces in, for example, South America. Politicians have an interest in presenting and explaining the benefits of regional integration but may also have a political interest in not moving too fast, if the electorate is sceptical. Once the system has been set up, it must include institutions that can guarantee and uphold the rules of the system. In such a context, the role of regional courts is essential: their independence and the capacity to enforce the rule of law at regional level are crucial in creating the foundations of a regional legitimacy. 
It is not a certain outcome and, in any event, states retain a wide margin of intervention in enhancing and, even more, preventing the build-up of such legitimacy. In the end, it is again up to the organisations - contrary to statesto prove, through their commitment and results, that they merit loyalty from citizens. In the current global system where states maintain their role as the legitimate actor of international relations, regional integration systems are ancillary factors. Therefore, significant issues that are very much still linked to national polities, such as democratisation, are mainly controlled by national politics and national institutions. In that sense, regional integration cannot impose itself on states in order to establish democracy but it can act as a stabilising and enhancing factor when such forces (democratisation forces) or policies appear and try to be applied at national level. The regional integration system may be the essential supporting factor that determines the success or failure of a nascent democratisation. Furthermore, regional integration systems can be important actors helping weak democracies fending off threats to democracy. This, however, puts a certain stress on the regional integration system. Regional integration is not an irreversible process but, contrary to states, regional organisations have to strive to maintain those elements of legitimacy they have achieved so far.

Professor Katrin Nyman-Metcalf is Head of the Chair of Law and Technology at Tallinn University of Technology and works as an international consultant mainly in the area of communications law. She has a PhD in public international law (law of outer space) from Uppsala University. Her research interests include communications law, the changing structure of governance and the implementation of human rights and the rule of law.

Dr. loannis Papageorgiou is assistant professor of European politics and the European Political System at the Aristotle University of Thessaloniki, Greece. He is a lawyer and political scientist with a PhD from the Université Libre de Bruxelles on regional integration in Central America. His research areas are i.a. European political integration and regional integration in other areas of the world. 


\section{References}

Acharya, A. (2006), 'Europe and Asia. Reflections on a tale of two regionalisms,' in B. Fort \& D. Webber (eds.) Regional Integration in East Asia and Europe: Convergence and Divergence, London: Routledge, pp. 312-321.

Albertini, M. (1999), "L'unificazione europea e il potere costituente", in Nazionalismo e Federalismo, Bologna: Il Mulino.

Bieber, R. (2009), 'The Lissabon-Urteil: an association of sovereign states,' European Journal of Constitutional Law, vol. 5, no. 3, pp. 395-405.

BVerfG (2009), Bundesverfassungsgericht (Germany), 30 June 2009. Retrieved (also in English) from http://www.bundesverfassungsgericht.de/entscheidungen/ es20090630_2bve000208en.html [accessed Dec 2015]

Centre for Studies on Federalism (2009), International Democracy Watch (Draft Project), January 2009.

Collins, R. (2009), 'Constitutionalism as liberal-juridical consciousness: echoes from international law's past,' Leiden Journal of International Law, vol. 22, pp. 251-287. http://dx.doi.org/10.1017/S0922156509005810

Deutsch, K. W. et al. (2003), 'Political Community and the North Atlantic Area,' in B. F. Nelsen \& A. Stubb (eds.) The European Union: Readings on the Theory and Practice of European Integration, 3rd edition, Boulder, CO: Lynne Renner Publishers, pp. 121-143.

De Witte, B. (2009), 'International law as a tool for the European Union,' European Constitutional Law, vol. 5, no. 2 (June), pp. 265-283.

Focarelli, C. (2012), International Law as Social Construct. The Struggle for Global Justice, Oxford: Oxford University Press. http://dx.doi.org/10.1093/acprof:o so/9780199584833.001.0001

Lake, D. A. (2009), 'Regional hierarchy: authority and local international order,' in Review of International Studies (British International Studies Association), vol. 35, Supplement S1, February 2009, pp. 35-58. http://dx.doi.org/10.1017/ cbo9781139087339.003

Marquez-Ramos, L.; Martinez-Zarzoso, I. \& Suarez-Burguet, C. (2011), 'Determinants of deep integration: examining socio-political factors,' Open Economies Review, vol. 22, no. 3, pp. 479-500.

http://dx.doi.org/10.1007/s11079-009-9132-x

Mather, J. (2006), Legitimizing the European Union: Aspirations, Inputs and Performance. London: Palgrave.

Mattli, W. (1999), The Logic of Regional Integration, Cambridge: Cambridge University Press. 
Nyman-Metcalf, K. (2013), 'Regional integration and sovereignty: the sum is more than its parts?' in P. Sevastik (ed.) Aspects of Sovereignty, The Hague: Martinus Nijhoff, pp. 83-100. http://dx.doi.org/10.1163/9789004232679_006

Nyman-Metcalf, K. \& Papageorgiou, I. F. (2005), Regional Integration and Courts of Justice, Antwerpen/Oxford: Intersentia. (2015), Democracy through Regional Integration, Antwerpen: Intersentia.

Schneiderman, D. (2006), 'Transnational legality and the immobilization of local agency,' in Annual Review of Law and Social Sciences, vol. 2, pp. 387-408.

Schütze, R. (2009), From Dual to Cooperative Federalism. The Changing Structure of European Law, Oxford: Oxford University Press.

Tang, S. (2006), 'Leadership in institution building. The case of ASEAN+3,' in B. Fort $\&$ D. Webber (eds.) Regional Integration in East Asia and Europe: Convergence and Divergence, London: Routledge, pp. 69-82.

Terada, T. (2006), 'The birth and growth of ASEAN+3' in B. Fort \& D. Webber (eds.) Regional Integration in East Asia and Europe: Convergence and Divergence, London: Routledge, pp. 218-235.

Von Bogdandy, A. (2008), 'The European Union as situation, executive and promoter of the international law of cultural diversity - elements of a beautiful friendship,' European Journal of International Law, vol. 19, no. 2, pp. 241-275.

Webber, D. (2006), 'Regional integration in Europe and Asia,' in B. Fort \& D. Webber (eds.) Regional Integration in East Asia and Europe: Convergence and Divergence, pp. 289-311.

Wheare, K. C. (1951), Federal Government, 2nd ed., London: Oxford University Press.

Williams, A. (2009), 'Philosophy of EU law,' Oxford Journal of Legal Studies, vol. 29(Autumn), pp. 549-577. 